\title{
The trouble with temporary: Impacts and pitfalls of a meanwhile community garden in Wythenshawe, South Manchester
}

\author{
Rebecca St. Clair ${ }^{\star}$, Michael Hardman, Richard P. Armitage and Graeme Sherriff \\ School of Environment and Life Sciences, University of Salford, M5 4WT, UK. \\ ${ }^{*}$ Corresponding author: r.stclair@edu.salford.ac.uk
}

Accepted 25 April 2017; First published online 6 June 2017

Themed Content: Critical Foodscapes

\begin{abstract}
The rise of Urban Agriculture projects across the UK has led to a surge of interest in their efficacy and resulting social impacts. Real Food Wythenshawe is a Lottery-funded urban food project in the UK that aims to teach the population of Wythenshawe to grow their own food and to cook from scratch. The area, popularly referred to as 'Europe's largest council estate', suffers from high levels of deprivation and has been described as a 'food desert' due to a perceived lack of access to fresh fruit and vegetables (Small World Consulting, 2013). In order to encourage Wythenshawe residents to grow their own food and to increase access to fresh fruit and vegetables, Real Food Wythenshawe aims to transform unused areas of land into growing spaces, such as allotments and community gardens. This paper focuses on research conducted at a community garden in Wythenshawe, established by Real Food Wythenshawe as an example of a 'meanwhile' or temporary growing site for people affected by cancer. The research investigated the impact of the growing activities on community garden participants through a series of observations and interviews. The findings suggest that the benefits of the space were multiple and diverse, ranging from increased growing knowledge to therapeutic effects, while there has been minimal effect on participants' dietary behavior. The organization of the community garden also raises questions over some of the practicalities of temporary urban growing sites and highlights the tensions that can arise between small community growing groups and larger institutions with control over land use. These findings add to a growing body of research that considers the value of growing in the city and reflects on the role of community gardening in deprived urban areas of the UK.
\end{abstract}

Key words: Urban Agriculture, community gardens, food security, meanwhile site, temporary

\section{Introduction: Urban Agriculture}

Broadly speaking, the term Urban Agriculture (UA) describes 'the rearing of livestock and/or produce in the city context' (Hardman and Larkham, 2014, p. 2). Types of UA range from the small scale, such as allotments, rooftop gardens, windowsills, beehives, community gardens or growing spaces in an around housing estates, to the larger scale of orchards, urban farms and land sharing schemes (Ackerman, 2012; Bryant, 2012; Battersby and Marshak, 2013; Tornaghi, 2014). UA is commonly discussed in relation to cities of the Global South (see, e.g., Mensah et al., 2001; Mougeot, 2005; Zezza and Tasciotti, 2010) and has been popular in North America for over $20 \mathrm{yr}$ (Tornaghi, 2014). In contrast, while private and allotment gardening in towns and cities have a long tradition in the UK, the commercial cultivation of crops in urban areas, as opposed to individuals growing for leisure or personal subsistence, is a relatively novel concept with the practice only recently gaining academic attention in Europe (Hardman and Larkham, 2014). Considering UA as a global phenomenon can be problematic, in that many of the factors affecting production and consumption in urban areas across the globe, such as rates of population growth, consumption patterns, cultural habits, proportions of wealth spent on food and susceptibility to fluctuations in food prices, are often not comparable (Orsini et al., 2013; Tornaghi, 2014). Battersby and Marshak (2013) observe that academics conceptualize UA in the Global South separately from UA in the North, with the former being led by development studies and the latter attracting interest from critical urban studies and food justice scholars.

While food production is a defining feature of many UA projects, it is not always viewed as the primary objective (Ackerman, 2012). Jac Smit, commonly referred to as 
the Father of UA (Nasr, 2009), argued that by closing the open loops of food systems in cities, UA could reduce resource use and help to introduce a more balanced economy (Smit and Nasr, 1992). UA may also be used to alleviate hunger and poverty in urban areas by supplying low-income residents with locally produced food (Smit and Nasr, 1992; Caputo, 2012), and by providing opportunities to learn new skills, which may later be used in seeking employment (Sustain, 2014). Furthermore, increased access to green space has been associated with higher levels of exercise, stress reduction and enhanced community cohesion (Howe et al., 2005; Small World Consulting, 2013; Sustain, 2014).

There is still much to explore regarding the true social benefits and controversies of growing in the city (Mougeot, 2000; Tornaghi, 2014). Until recently, the narrative of UA has portrayed the practice in a largely positive light with numerous accounts written from an advocacy perspective, and there is scarce research highlighting the limitations or adverse effects of UA (Battersby and Marshak, 2013; Orsini et al., 2013; Tornaghi, 2014). As the number of both grassroots and formal UA initiatives rises across the UK, critical scholars [see, e.g., Tornaghi (2014)] call for greater consideration of the more contentious areas of UA, including its potential to entrench neoliberalism or exacerbate forms of social injustice and exclusion.

While acknowledging the tendency for UA projects to support the 'rolling back of the social safety net' as nonprofit organizations fill the void created by austerity measures, McClintock (2014, p. 1) argues that UA is both radical and neoliberal. It is radical in its enduring association with grassroots movements seeking to oppose the dominant food system, but neoliberal, in the sense that projects must function within the neoliberal structures of society and in doing so, must reproduce and further entrench certain aspects of that framework. In refusing to acknowledge and accept the contradictions inherent in UA, we may fail to utilize its transformative power. The relevance of UA to the food justice movement and its potential to encourage structural reconfiguration from the grassroots by providing 'radical alternatives to the capitalist neoliberal organization of urban life' (Tornaghi, 2014 , p. 2) raises interesting questions regarding the motivations driving 'institution-led', or formal UA projects.

This paper highlights the impacts of a meanwhile community garden in the context of some of the barriers encountered as a result of the temporary nature of the site. While accepting that the actions of the growing group members could be interpreted as radical or subversive, observations suggested that this was not intentional and that their activities could be better described using the concept of 'Do It Yourself (DIY) citizenship' (Crossan et al., 2016). Furthermore, the barriers encountered as a result of the precarious nature of temporary spaces allow consideration of the conflict between use and exchange value when considering decisions regarding land use and involving land users. The following section introduces the UA project from which the community garden stemmed and begins with a description of Wythenshawe, the district in South Manchester where the project is based.

\section{Wythenshawe: A Garden City for the 21st Century?}

Wythenshawe, a district of Manchester in the UK, was designed during the interwar period as part of the garden city movement. The design encouraged urban growing with the provision of space for food cultivation to bring residents 'back to the land' and increase access to fresh food (Howe and Wheeler, 1999; Hall, 2002; Battersby and Marshak, 2013). As Barry Parker, the urban planner leading the development stated:

"The objective is to secure around the house the air space requisite for health, to grow vegetables and fruit for our table...to surround ourselves with pleasant places in which to live and work, rest and play, and to entertain friends."

[Barry Parker, quoted in Hollow (2011, p. 5)]

In reality, however, Hardy (2005) claims that the plans for Britain's third garden city were doomed from the start, and that what resulted was 'little more than another large estate', due in part to the intended population of Wythenshawe being over three times the upper limit envisioned in Ebenezer Howard's model (Hardy, 1992, p. 198). While Wythenshawe has been marketed as one of the earliest garden cities and referred to as a Garden City for the 21 st century, Hardy (2005, p. 5) asserts that Howard would have 'turned in his grave' had he known that Wythenshawe was promoted as a true example of a garden city.

Regardless of its disputed right to the title of Garden City, Wythenshawe boasts an abundance of green space when compared with the rest of Manchester, and many properties still benefit from gardens and fruit trees (Real Food Wythenshawe, 2015). Wythenshawe's central shopping area contains a diversity of shops and facilities, in contrast with the wider district where few outlets are available for residents to purchase fresh, healthy food. Wythenshawe has consequently been referred to as a food desert, a term contrasting starkly with the ideal of a garden city (Small World Consulting, 2013). Existing levels of deprivation and lack of access to fresh fruit and vegetables suggest that present-day Wythenshawe has strayed far from the green aspirations of its original design.

\section{Real Food Wythenshawe and the Macmillan Community Garden}

Real Food Wythenshawe (RFW) is a 5-yr Lottery-funded urban food project, run by staff based at Wythenshawe 
Community Housing Group (WCHG), a social housing provider in Wythenshawe and the project's lead partner. Three main project themes: growing, cooking and learning, are encompassed within five key 'flagship' areas. One flagship, 'green spaces to growing spaces', identifies unused areas of land considered suitable for use by community growing groups. The study site providing the focus of this paper, the Macmillan community garden, was situated on the first piece of land that RFW secured from WCHG and was developed in partnership with the Macmillan Cancer Support charity for people affected by cancer.

The Macmillan community garden was established in October 2013 and ran until July 2016 when the land was claimed back by WCHG for housing development. During this time, the community garden participants met every week under the co-ordination of a Macmillan volunteer. The growing site was located in Benchill, an area of particular deprivation in Wythenshawe; ranking 441 of 32,844 on the Index of Multiple Deprivation, with 1 being the most deprived and 32,844 being the least deprived (Open Data Communities, 2015).

\section{Methods}

Research techniques included participant observation, semi-structured interviews and group interviews to provide an in-depth investigation of the impacts and perceptions of community garden participants. The exploratory nature of the research necessitated the use of qualitative methods, as the required depth of information regarding lived experience could not be adequately captured using quantitative techniques (Silverman, 2010). Numerous recent studies have highlighted the suitability of observation and interview for surveying UA projects and groups (e.g., Sherriff, 2008; Colasanti et al., 2012; Hardman and Larkham, 2014; Tompkins, 2014).

Following initial scoping of suitable case study sites, site selection and identification of a gatekeeper, fortnightly observations of morning sessions ran from April until December 2015. Rapport was built with the group through participation in growing activities and informal interviews in addition to keeping field notes and taking photographs. Four final site visits took place during the 2016 growing season shortly before the group's activities ended and the site was taken back for housing development. As per the role of 'participant as observer', members of the group were aware of the researcher's role from the outset (Gold, 1958, p. 220).

Eight people were in regular attendance at the growing sessions, of whom six took part in an initial group interview and seven were subsequently interviewed individually. A final group interview with six participants was held in June 2016. Interviews were recorded using an audio recorder and manually transcribed by the researcher. Analysis employed a constructivist-grounded theory approach whereby thematic categories were developed using NVivo 11 through a process of open coding, constant comparative analysis and axial coding. The next section describes the community garden, critically analyses the impacts of participation and discusses the complications brought about by the precarious nature of temporary land use and the divergent values held by stakeholders. Interviewees' names have been changed to retain anonymity.

\section{Description of the Growing Site and Group Members}

The growing site does not fit easily into a traditional UA typology. Group members referred to the site as the 'Macmillan allotment'; however, the space did not reflect the traditional description of an allotment, defined by the 1922 Allotment Act as:

"An allotment not exceeding forty poles in extent which is wholly or mainly cultivated by the occupier for the production of vegetable or fruit crops for consumption by himself or his family."

(Local Government Association, 2009, p. 4).

The site measured approximately one-quarter of an acre (40 poles), so was at the upper end of the specified area for an allotment. However, rather than being split into individual plots, the space was communal, with the group members meeting at a specific time every week, working together and sharing the produce. On first sight, the space resembled a community garden, with a group of people gathering weekly to grow fruit and vegetables together; however, it was not open to the public and the majority of group members travelled from other areas by car to attend the sessions. Nevertheless, given that 'a community may not be physically or geographically defined, but may be a community of interest or of shared philosophy' (Holland, 2004, p. 288), the fact that access to the site was reserved for a specific group of people other than local residents, should not necessarily exclude the Macmillan growing site from the title of 'community garden'.

The group did initially consider having separate plots to allow individual participants to work on their own allocated spaces. As a Macmillan volunteer explained:

"We found that didn't work because...they might not turn up...they might be undergoing chemotherapy or going through a bad patch...so eventually we decided that it was probably going to be better if we all pitched in to all of it."

(Daniel, group interview July, 2015)

Sharing space and working toward a common goal suited the participants well and everybody felt that they had agency in decision-making processes. The democratic nature of the group was clear throughout the research, with members consulting one another on every aspect of 
their endeavor; from the types of vegetables grown, to the location of the water supply and the color of paint used for the shed. Holland (2004) observed that while many community gardens are born from the ideas and hopes of an individual, projects like the Macmillan community garden can only really achieve sustainability with continued and evolving participation from members.

Of the eight people who regularly attended the weekly growing sessions, five became associated with the community garden through their involvement with Macmillan. Of these, three had been affected by cancer and two were Macmillan volunteers. Two others became aware of the growing group through living locally, and one was asked to join because of her growing expertise. Most participants were retired men of various employment backgrounds including engineering, butchery, horticulture and further education. The two exceptions were a self-employed woman, and a male college student. Half of the group members were Wythenshawe residents and the remainder lived outside Wythenshawe. UA schemes have a tendency to attract the same types of white, middle class people, who can afford to give spare time to such projects, with Alkon and Agyeman (2011, p. 3) describing this demographic as something of a 'monoculture'. In this respect, the Macmillan community garden largely failed to reach beyond the usual suspects of UA projects. Given that the RFW project identified a particular need within Wythenshawe and specifically sought to help Wythenshawe residents by increasing growing opportunities and access to fresh produce, it is perhaps surprising that only half of the group members lived in Wythenshawe, with the remaining members traveling from more affluent surrounding areas. Informal interviews with local residents not involved in the growing activities suggested that although there was a general feeling of approval of the garden in terms of its aesthetics and purpose, there was little desire from those approached to become directly involved.

\section{Impacts: Produce}

Most vegetables grown at the site were taken to the local hospital in exchange for donations for the Macmillan charity and for maintenance of the plot. The group decided what to grow based on the types of vegetables people would ordinarily like to buy. While the group focused on producing vegetables for the hospital stall, they found that people were occasionally unwilling to try unfamiliar vegetables:

"We have tried to get a balance so that we produce some things that are a bit more unusual, but still retaining good quantities of vegetables that people recognise and want to eat."

(Daniel, interview September, 2015)

The majority of customers were hospital staff, who quickly became used to the regularity of the stall.
People could pay whatever they chose. Group member Bob explained:

“...some people just walk up, pick up a lettuce or whatever they want and just walk away and don't put a donation down and...that's ok. Quite a few...donate more than the plants are actually worth."

(Bob, interview August, 2015)

This type of exchange could be compared with the 'sliding scale food stand' described by McClintock (2014) illustrating the decommodification of food by viewing it as a beneficial entity rather than a profitable asset. McClintock (2014, p. 148) states, 'projects such as these arise in an attempt to subvert the industrial agri-food system', and while this is the driving force behind a number of radical UA projects, it seems unlikely that this was a major motivation for the Macmillan growers. Instead, members sought to help others, driven by compassion and empathy rather than an explicit rejection of the geopolitics of commercial food production. Observations demonstrated that the members of the growing group were proud of the vegetables they produced and were motivated by the idea that the activities at the site enabled them to give something back to Macmillan. This could be viewed as a demonstration of 'DIY citizenship', described by Crossan et al. (2016, p. 5) as:

"a form of citizenship that is generative of collaborative social relations and new urban places, while also being disruptive, in unsettling neoliberalism's penchant for atomized individuals and reversing its frequently wasteful spatial practices."

The group's activities increased the availability of fresh, local produce in Wythenshawe but did not directly increase access to fruit and vegetables for residents of the particularly high area of deprivation in which the activities took place. Although the idea of holding a vegetable stall for local residents was discussed, it did not come to fruition, as the group did not wish to create a demand that they could not guarantee to meet on a regular basis.

\section{Impacts: The Therapy of Watching Plants Grow}

The impacts of involvement with the growing site were varied and wide-ranging. The themes raised in interviews included the therapeutic effects of growing, the social impacts felt by the group and the development and sharing of growing knowledge. A significant consideration for the group organizers was the provision of help and support for recent cancer patients during their recovery process. An informal interview with a member of staff at the Macmillan center in Wythenshawe hospital confirmed the center's determination to provide as many different ways of assisting people through their 
experiences as possible. The member of staff described people who have recently undergone chemotherapy or radiotherapy as feeling as though 'they have been thrown out of a cement mixer'. For John, a member of the community garden, it was clear that he valued the time he spent at the site every Thursday:

"The best thing about the site for me, I just see it as a kind of therapy...takes you away from your problems really...If you're thinking about your illness all the time, it just consumes you. I've seen this as, it's an outlet, only for a couple of hours a week, but it's definitely an outlet...It's therapy. Watching things grow."

(John, interview July, 2015)

The therapeutic effects of the community garden were raised during a number of interviews. The concept of therapeutic landscapes is well-established (Gesler, 1993; Pitt, 2014) and as Battersby and Marshak (2013, p. 451) note, there is a growing body of literature on the benefits of green space for areas such as stress reduction and well-being that they term 'horticulture therapy' (see, e.g., Grahn and Stigsdotter, 2003). Unruh et al. (2000, p. 7) use the concept of 'Attention Restoration' in their analysis of gardening activities among people who suffer from cancer. The theory comprises four main characteristics: 'fascination', where a participant is compelled to give the task at hand their whole attention; 'being away', the feeling of being removed from otherwise stressful thoughts or environments; 'extent', the capacity of the gardening environment to draw people in through its richness; and 'compatibility', the way in which the participant fits into the surroundings and the appropriateness of the tasks. All of these characteristics were visible in the Macmillan community garden with the concept of 'being away' neatly capturing John's feelings regarding his visits to the site.

A recurrent theme throughout the interviews is the enjoyment the group members derived from seeing plants grow, feeling responsible for them, being 'fascinated' by their progress and having a sense of control over them.

\footnotetext{
"I think what people get really is watching a plant going from small to massive, and I mean I get the hit on that...I enjoy that."

(Tony, group interview July, 2015)

"It's a sense of thinking well I did that. I've made that happen. You sort of become attached to them, and...you kind of feel in control of them."

(Daniel, group interview July, 2015)
}

The reflection of human-nature relations in gardening is not new (see, e.g., Bhatti and Church, 2001) and in a project that explored gardening as an activity conducted by people with long-term illnesses, Unruh et al. (2000) demonstrated that the subjects of their study considered the human interaction with nature that gardening allows an important motivating factor. As Battersby and Marshak (2013, p. 451) observe, the research on horticulture therapy investigates the way in which gardening 'can enforce a self-worth and appeal to the human spirit as well as benefit people's health'. Furthermore, Sempik et al. (2005)'s detailed study of 'Therapeutic Horticulture in the UK' discusses the benefit of access to 'nature, freedom and space' and highlights the escapism that can be felt through experience of the outdoors. The experience of the Macmillan community garden offered some group members a moment of calm and a temporary escape from the stresses of their experiences, while for others, it had the effect of increasing selfconfidence enabling participants to emerge from relative isolation and to socialize within the group.

\section{Impacts: Socializing and Mutual Support}

From early visits to the site, it was clear that the social aspects of the growing group were as important as the growing itself. Matthew, a group member, noted that the participants would attend the sessions regardless of how rich or poor the harvest proved to be.

"If nothing grew, we would still be here, trying to make it grow I'm sure... because you like to see the fruits of your labours and what not. But, it's just nice to be here."

(Matthew, interview October, 2015)

The sessions provided an opportunity for people to be in the company of others with similar experiences. For John, Thursday mornings served as a valuable chance to socialize with the group:
"He's been through hell but he's gotta go through hell again, and he's going to make sure he comes down for a cup of tea... because he can talk to the group rather than the family."
(Graham, interview August, 2015)

In addition to the supportive environment that drew participants to the sessions, most of the group members enjoyed the jovial atmosphere that was clear from early visits to the site:

"...I just like being out. And the craic that we get here is, you know... It's men jibbing with men really. It's good fun, a bit of relaxation."

(Matthew, interview October, 2015)

Tony and Jarred, who live close to the site, were frequently mentioned when members discussed social impact. Although neighbors, they did not interact with one another before their involvement with the community garden and Tony had felt socially isolated for a number of years. Tony admitted that the weekly sessions allow him to 'get to know what is going on in the world'. The same was often said of Jarred, who enjoyed socializing with the other participants and became a valued member of the group:

\footnotetext{
"...you can see the change in Jarred now. He's come out of himself...you can see how sociable he is now... that's what this has done."

(Graham, interview August, 2015)
} 
The social aspects of the group held great importance for the participants who valued the opportunity to meet, have discussions over a cup of tea, joke and relax. This observation supports Holland (2004)'s assertion that one of the strengths of community gardens is that their benefits are diverse, and are not restricted to the food growing itself. This 'multiplicity' Holland (2004, p. 303) argues is significant in that it provides 'value for money' when a number of outcomes can be accomplished through one activity.

\section{Impacts: Growing Knowledge and Dietary Impact}

As discussed above, the work of the growing group temporarily contributed to an increased availability of fresh food by supplying fruit and vegetables to the local hospital for consumption by the public. This benefited not only the people at the hospital, who could buy the produce for as much or as little as they liked, but the Macmillan charity and the group itself. Access to fruit and vegetables also increased on a smaller scale within people's homes. As members learnt how to grow fruit and vegetables, they harnessed the skills they gained at the community garden and used them in their own gardens. As Daniel pointed out, this was one of the intended consequences of growing together:

"If you're growing something at home and something goes wrong or you're not sure about something you can bring it up with us here and we can share the ideas and then you can go away and do it and see how it turns out."

(Daniel, group interview July, 2015)

As a result of his time spent at the community garden, John purchased a raised bed for his garden at home, while Bob felt that his involvement with the group gave him the confidence to use his newly acquired skills to grow his own food. The growing activity reached further than the participants' own homes and Bob shared his garden vegetables with a next-door neighbor and a family across the road:

"I've actually given quite a lot to neighbours...It saves them cash but also it develops a really good relationship with them." (Bob, interview August, 2015)

Bob's resulting enthusiasm spread to three or four otherwise unconnected people in his local area, and it is possible that this had a wider effect if the interest in growing was dispersed further. This demonstrates the 'ripple' effects of UA projects that can extend further than is immediately visible (Westphal, 2003, p. 138). These external impacts would be challenging for a project such as RFW to monitor and report, as they take place away from the site of research and become apparent only through sustained interaction with participants of the group.
While the association between increased intake of fruit and vegetables and community gardening has been made previously (see for instance: Alaimo et al., 2008), most participants did not feel that their experience at the community garden affected the types of food they consumed. Observations and informal interviews suggest that the majority of the group members had access to fresh fruit and vegetables and did not struggle to provide themselves with a healthy, balanced diet. However, the practice of growing vegetables influenced participants' preference for home-grown vegetables rather than shop-bought, where possible. This was predominantly due to the difference in taste:

"Yeah, it is definitely the flavour. It's the taste. It's totally different if you go into a shop and buy vegetables "cause...they taste sweeter when you actually grow them."

(Tony, group interview July, 2015)

"I grew a cucumber last year. I didn't know what a cucumber should taste like until last year and we had to buy one this week because they [weren't ready]. They're absolutely tasteless and full of water, and the difference is unbelievable."

(Bob, group interview July, 2015)

Similar to the way that the group could be seen to be subverting the dominant food system by exchanging food for donations at the hospital stall, they also chose not to buy certain vegetables from supermarkets where they felt they had the opportunity to grow them instead. This was not in protest, nor did they seek to boycott supermarkets, it was a choice based on preference and taste with the unintentional effect of the appearance of subversion.

While Tony enjoyed eating the vegetables that he grew himself, he found that his children were more difficult to convince:

“My kids wouldn't eat it... Because I grew it, they won't eat it... They say, 'Oh no, I'm not eating that. Slugs have been round it!'."

(Tony, interview October, 2015)

The revulsion inspired by home-grown food may seem surprising, but given that our food system is predisposed to present food that is clean in its appearance, uniform in shape and has no visible connection with its place of production, it follows that people may be deterred by an honestly presented vegetable. It is this disconnection that UA seeks to mend by bringing production closer to the consumer; however, the example of Tony's children suggests that it may take some time to normalize the rustic appearance of home-grown vegetables and to recondition the populace to expect muddy or wonky vegetables as standard.

\section{Temporary Spaces: The Tacit Assumption of Permanence}

The impacts of the community garden, while significant, should be considered in the context of the precarious nature of temporary spaces. In summer 2016, WCHG 
notified the group of their plans to develop the plot into housing in 2017 and the group decided to cease growing activities rather than relocate to another site. Through repeated site visits and extended conversations with group members, it seemed that although the group was aware they would not have indefinite use of the land, they did not consciously expect the housing group to claim it back. In conversation, statements regarding the future development of the site were frequently formed using 'if' rather than 'when', permanent features such as fruit trees became part of the landscape and plans for the coming months and years were discussed. The time and effort invested in the space made it evident that the group members had formed an emotional attachment to the garden:

"I think it's just the right size and it's got the right amenities on it. We've improved the amenities, that's why I got my table and the big umbrella... Obviously I think we'd be devastated if they took it away from us."

(John, interview July, 2015)

"Well if they build on it, it'll be a disaster really I think. If you're going to build, then build somewhere else. That's my opinion."

(Tony, interview October, 2015)

Another indication that the group had not fully embraced the temporary nature of the site was their preference to grow in the ground rather than in raised beds or temporary containers. When asked about the possibility of growing in mobile containers such as skips, Tony, a group member and local resident, responded with disbelief:

"Grow it in skips?!...God, can you imagine how many skips? How many plots have we got here? [counts to ten] You want about ten big skips...It would cost you more to put the soil in them...And then you've got to lift them. And move them to the sites...Not a good idea, no."

(Tony, interview October, 2015)

Tony's rationale for rejecting of the idea of growing in mobile containers was not limited to the practical difficulties presented by skips. His disapproval extended to the entire concept of growing in alternative containers, as he saw growing in the ground as more traditional:

"This is the old-fashioned way to grow things... You take that away, it defeats the interest. Gone."

(Tony, interview October, 2015)

Group members also reflected that if the site were to move, it would affect Jarred and Tony most acutely, as they would struggle to travel the distance to a new location. As Matthew notes:

"If [the site is] moved, I don't know what Tony would do to be honest with you. It would be very difficult... I think it would really hurt Tony."

(Matthew, interview October, 2015)

One of the aims of RFW was to encourage Wythenshawe residents to grow their own food. Of the four group

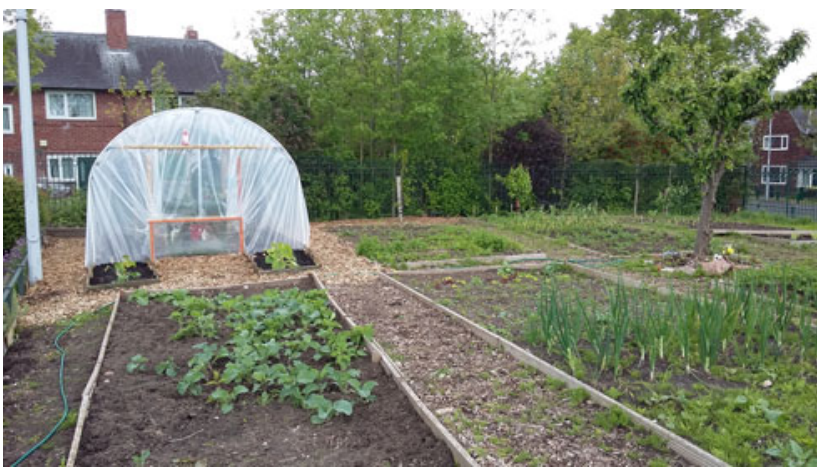

Figure 1. The Macmillan community garden polytunnel.

members who lived in Wythenshawe, two would not have the means to reach a new site if the group had decided to relocate. Holland (2004) has observed the importance of secure land tenure for the sustainability of a community garden, as uncertainty over the length of time the group has the use of the land may act as a barrier for its development and lead to a paucity of incentive for engagement.

\section{Temporary Spaces: 'A Lot of Hard Work'}

In recommending interstitial spaces for use as growing sites, it is tempting to imagine that areas of unused land can be transformed into productive gardens with minimal effort and expense. This was not the case with the Macmillan site, which was not garden-ready from the outset. The area needed to be cleared of refuse and there was no water supply, equipment or shelter. WCHG installed a water supply at a cost of approximately $£ 3000$ on behalf of RFW, who later provided a polytunnel for the site, aiming to increase yield and extend the growing season (see Fig. 1). The group received external contributions of topsoil, wood chips, mulch and a corrugated iron container, used for storage and shelter and referred to by the group as their 'MacDen' (see Fig. 2). As Daniel explained:

"When we came here at first the land was terrible because of what had gone before... The soil condition takes time to build up so if you're only here for say three years, you're just getting the soil into decent growing conditions and then you've got to give it all up to move somewhere else... So then it's another three years to build it up."

(Daniel, group interview July, 2015)

Although Graham, the group's organizer, was proud of the community garden's achievements, he had reservations about the prospect of starting another community garden elsewhere:

"If we do move from here, would I have the energy, would I have the push, knowing what's ahead of me to do it all again?...What I've come through, that is a lot of hard work." (Graham, interview August, 2015) 


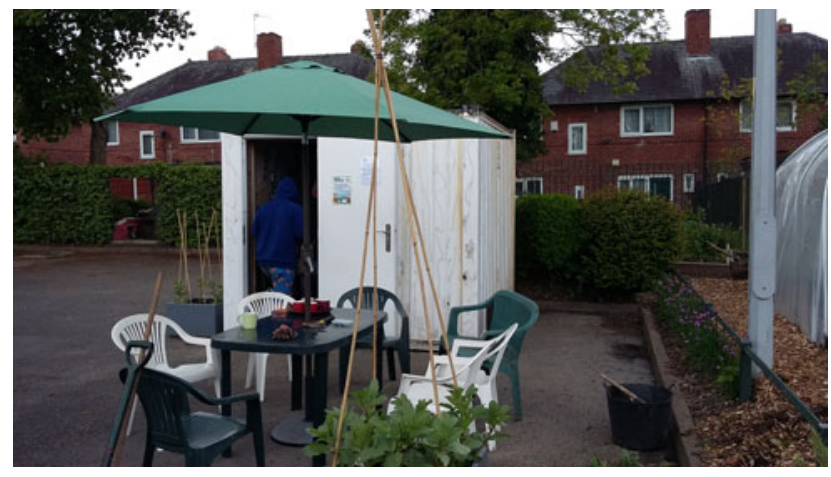

Figure 2. The 'MacDen'.

\section{Temporary Spaces: Land Users and Landowners}

Schmelzkopf (2002) notes the significance of both scale and value for decisions regarding land use, and varying contexts provide contrasting priorities (Smith and Kurtz, 2003). While space for gardening and socializing may be important for individuals at the grassroots, landowners may see more value in development. Observations at the Macmillan community garden demonstrated that given this mismatch in perceptions of use value and exchange value, effective communication between the two parties is crucial, with transparency in decisionmaking being an important aspect of a fruitful relationship between land users, landowners and intermediaries. An element of distrust was instilled in the members of the Macmillan community garden in the early stages of the project, following the group's discovery that WCHG had already made plans to build on the site prior to the community garden's official opening ceremony:

"What they did in February last year was very naughty...We had it opened by [the local MP]...in the October. I saw the drawings and they were actually approved in the August... [The local MP] didn't know anything about it. If he was alive today he would've played merry hell."

(Graham, group interview July, 2015)

Following the latest notification that the land would be claimed back by WCHG in 2017, the group was evidently upset at the prospect of relinquishing the site but was also resigned to the idea that it belonged to the housing group and that they were powerless to stand in the way of development:

\footnotetext{
"You can't tell them what to do anyway...They're short of houses, they're gonna do it... and it's their land. So what can you do?"

(Tony, interview October, 2015)
}

The idea of entering a dialog with WCHG in an attempt to keep the land or to extend their use of it did not feature in any of the interviews. As Ghose and Pettygrove (2014) note, in communities, or networks, members with less status or 'political clout' frequently find themselves complying with the wishes of actors who hold more power. This acceptance was perhaps strengthened by the decision of two key group members to move to other areas, making it infeasible for them to travel to Wythenshawe to attend future growing sessions. The decision not to relocate to another site was also influenced by the effort that had been required to establish the community garden and the organizer's reluctance to repeat the process.

\section{Temporary Spaces: Reflections from the Group}

Following the group's experience, they all agreed that they would not be interested in setting up another meanwhile growing site and offered the following advice for groups in a similar situation:

\footnotetext{
"Don't take on a temporary plot....Make sure that wherever you start up that it's your organisation that's doing it and you've got a long term length of time to be there rather than being faced about 18 months into the project that you only have so much time left on it, which kills everybody's enthusiasm."

(Daniel, group interview June, 2016)
}

Daniel's suggestion that growing groups should secure land with the landowners directly rather than relying on a third party is a comment on the group's relationship with RFW. Through a series of disagreements earlier in the project, communications between RFW and individual members of the community garden became increasingly tense. On reflection, some group members considered their connection with RFW to have been a destructive influence, suggesting that, as Sadie and Bob put it in the final group interview, 'the association with Macmillan' showed RFW in a beneficial light and they 'only did it for what they could get out of it'. Daniel shared the suspicion that the group had been set up in order to benefit RFW:

\footnotetext{
"We thought it was a genuine interest and actually on reflection it was possibly their kudos that they were interested in and we were just a tool that they could manipulate to get that." (Daniel, group interview June, 2016)
}

The disappointment toward the end of the group's activities was palpable and John's comments in the final group interview regarding the site closure perhaps best sum up the sentiments expressed during later observations:

"I'm absolutely disgusted this place is shutting down...So we're all gutted. Gutted in the way it's going to go. We didn't deserve that."

(John, group interview June, 2016)

\section{Conclusion}

Findings from the Macmillan community garden demonstrate that the impacts on participants were wide-ranging. 
The collaboration between two organizations enabled the successful initiation and development of the community garden, but through clashes of priorities and difficulties with communication, the association proved to be divisive. The involvement of a special interest organization allowed the community garden to act as safe space for the Macmillan participants, but led to the exclusion of other potential participants and hindered RFW's goal of reaching their target group of people in Wythenshawe who struggle to access fresh food. Given that RFW aims to teach Wythenshawe residents to grow their own food and that a large aspect of their work focuses on pro-environmental behavioral change through the adoption of sustainable diets, it is perhaps surprising that the community garden had very little impact on the dietary behavior of Wythenshawe residents.

Community gardens have received attention for being perceived as either radical (Mckay, 2011), or neoliberal in their outcomes (Pudup, 2008), or as being both radical and neoliberal by necessity (McClintock, 2014). While acknowledging the susceptibility of community gardening to the entrenchment of a neoliberal hegemony, Crossan et al. (2016) argue that this should not detract from a group's ability to effect political practice through 'Do It Yourself' citizenship, whereby group members can re-evaluate their relationship with the environment and with each other through community gardening. This account has more resonance for the Macmillan group members, who were not consciously politically motivated, nor did they actively seek radical alternatives to our capitalist way of life.

The impacts of the site included an opportunity to socialize and a space for temporary escape. The activities of the growing site also provided a new outlet for fresh, local vegetables in Wythenshawe at the local hospital. The multiplicity of impacts of the community garden could be seen to support Holland (2004)'s suggestion that these types of UA sites can represent good value for money for local investment. Schmelzkopf (2002) and Smith and Kurtz (2003) note that community gardens tend to be measured by their use value in that their associated impacts are often immaterial, making any calculation of their financial value problematic, if irrelevant. This tension highlights one of the difficulties presented by actors at different scales having contrasting perceptions of value, and points to a greater need for more effective communication between landowners and land users.

The experience of the Macmillan community garden demonstrates that while temporary growing sites have the potential to offer multiple benefits to participants, the production of such spaces does not occur without significant investment from organizers and members. Without secure tenure, sustaining growing projects can be problematic and the prospect of being deprived of the fruits of their labor can leave community members feeling disheartened or exploited rather than empowered.
Acknowledgements. This research was part-funded by the Big Lottery through Real Food Wythenshawe.

\section{References}

Ackerman, K. 2012. Urban agriculture: Opportunities and constraints. In F. Zeman (ed.). Metropolitan Sustainability: Understanding and Improving the Urban Environment. Woodhead Publishing Limited, Cambridge, UK. p. 118-146.

Alaimo, K., Packnett, E., Miles, R.A., and Kruger, D.J. 2008. Fruit and vegetable intake among urban community gardeners. Journal of Nutrition Education and Behavior 40(2): 94-101.

Alkon, A.H., and Agyeman, J. 2011. Cultivating food justice: race, class, and sustainability. Cambridge, Mass; London: MIT Press.

Battersby, J. and Marshak, M. 2013. Growing communities: Integrating the social and economic benefits of urban agriculture in Cape Town. In Paper presented at the Urban Forum.

Bhatti, M. and Church, A. 2001. Cultivating natures: Homes and gardens in late modernity. Sociology 35(2):365-383. doi: $10.1177 / \mathrm{s} 0038038501000177$

Bryant, C. 2012. The Discovery of Urban Agriculture. In Paper presented at the COST Action Urban Agriculture Europe: Documentation 1st Work Group Meeting, Aachen.

Caputo, S. 2012. The purpose of urban food production in developed countries. In A. Viljoen and J.S.C. Wiskerke (eds). Sustainable Food Planning: Evolving Theory and Practice. Wageningen Academic Publishers, Wageningen. p. 259-270.

Colasanti, K.J., Hamm, M.W., and Litjens, C.M. 2012. The city as an" agricultural powerhouse"? perspectives on expanding urban agriculture from Detroit, Michigan. Urban Geography 33(3):348-369.

Crossan, J., Cumbers, A., McMaster, R., and Shaw, D. 2016. Contesting neoliberal urbanism in Glasgow's community gardens: The practice of DIY citizenship. Antipode 48(4): 937-955.

Gesler, W.M. 1993. Therapeutic landscapes: Theory and a case study of Epidauros, Greece. Environment and Planning D: Society and Space 11(2):171-189.

Ghose, R. and Pettygrove, M. 2014. Actors and networks in urban community garden development. Geoforum 53:93-103. doi: http://dx.doi.org/10.1016/j.geoforum.2014.02.009

Gold, R.L. 1958. Roles in sociological field observations. Social Forces 36(3):217-223.

Grahn, P. and Stigsdotter, U.A. 2003. Landscape planning and stress. Urban Forestry and Urban Greening 2(1):1-18. doi: http://dx.doi.org/10.1078/1618-8667-00019

Hall, P. 2002. Cities of Tomorrow: An Intellectual History of Urban Planning and Design in the Twentieth Century. 3rd ed. Blackwell, Oxford.

Hardman, M. and Larkham, P.J. 2014. Informal Urban Agriculture: The Secret Lives of Guerilla Gardeners. Springer, London.

Hardy, D. 1992. The garden city campaign: An overview. In S. Ward (ed.) The Garden City: Past, Present and Future. Chapman \& Hall, London. p. 187-209.

Hardy, D. 2005. Garden cities: Practical concept, elusive reality. Journal of Planning History 4(4):383-391. doi: 10.1177/ 1538513205281614. 
Holland, L. 2004. Diversity and connections in community gardens: A contribution to local sustainability. Local Environment 9(3):285-305.

Hollow, M. 2011. Suburban ideals on England's interwar council estates. Garden History 39(2):203-217.

Howe, J., Viljoen, A., and Bohn, K. 2005. New cities with more life: Benefits and obstacles. In A. Viljoen and J. Howe (eds). Continuous Productive Urban Landscapes. Architectural Press, Oxford, UK.

Howe, J. and Wheeler, P. (1999). Urban food growing: The experience of two UK cities. Sustainable Development 7(1):13.

Local Government Association 2009. Growing in the community. 2nd ed. Retrieved from http://www.local.gov. uk/c/document_library/get_file?uuid=28d8ca84-9f61-45509c84-6e9d04bda872.

McClintock, N. 2014. Radical, reformist, and garden-variety neoliberal: Coming to terms with urban agriculture's contradictions. Local Environment 19(2):147-171. doi: 10.1080/ 13549839.2012.752797.

Mckay, G. 2011. Radical Gardening: Politics, Idealism \& Rebellion in the Garden. Frances Lincoln, London.

Mensah, E., Amoah, P., Drechsel, P., and Abaidoo, R. 2001. 2.3 Environmental concerns of urban and peri-urban agriculture: Case studies from Accra and Kumasi. In P. Drechsel and D. Kunze (eds). Waste Composting for Urban and Peri-urban Agriculture: Closing the Rural-urban Nutrient Cycle in sub-Saharan Africa, CABI Publishing, Wallingford, Oxon, New York. p. 55.

Mougeot 2000. Urban agriculture: Definition, presence, potentials and risks. In S. Gundel, M. Dubbeling, H. de Zeeuw, N. Bakker and U. Sabel-Koschella (eds). Growing Cities, Growing Food: Urban Agriculture on the Policy Agenda. Deutsche Stiftung für internationale Entwicklung (DSE), Feldafing, Germany.p. 1-42.

Mougeot 2005. Agropolis: the Social, Political, and Environmental Dimensions of Urban Agriculture. Earthscan, London; Sterling, VA.

Nasr, J. 2009. Jac Smit (1929-2009)—Father of Urban Agriculture, City Farmer. Available at Web site http://www.cityfarmer.info/ 2009/11/17/jac-smit-1929-2009-father-of-urban-agriculture/.

Open Data Communities 2015. Indices of Deprivation 2015 Explorer. Available at Web site http://dclgapps.communities. gov.uk/imd/idmap.html (verified 10/03/2016).

Orsini, F., Kahane, R., Nono-Womdim, R., and Gianquinto, G. (2013). Urban agriculture in the developing world: A review. Agronomy for Sustainable Development 33(4):695720. doi: 10.1007/s13593-013-0143-z.
Pitt, H. 2014. Therapeutic experiences of community gardens: Putting flow in its place. Health \& Place 27:84-91.

Pudup, M.B. 2008. It takes a garden: Cultivating citizen-subjects in organized garden projects. Geoforum 39(3):1228-1240. doi: http://dx.doi.org/10.1016/j.geoforum.2007.06.012

Real Food Wythenshawe 2015. Real Food Wythenshawe. Available at Web site http://realfood.cc.demo.faelix.net/ growing (verified 17/02/2015).

Schmelzkopf, K. 2002. Incommensurability, land use, and the right to space: Community gardens in New York City1. Urban Geography 23(4):323-343.

Sempik, J., Aldridge, J., and Becker, S. 2005. Health, Well-being, and Social Inclusion: Therapeutic Horticulture in the UK. Policy Press, Bristol, UK.

Sherriff, G. 2008. Towards healthy local food: Issues in achieving Just Sustainability. Local Environment 14(1):73-92. doi: 10.1080/13549830802522566.

Silverman, D. 2010. Doing Qualitative Research: A Practical Handbook. 3rd ed. SAGE, London.

Small World Consulting 2013. Sustainable Food in Manchester: Final Report. Lancaster Environment Centre, Lancaster.

Smit, J. and Nasr, J. 1992. Urban agriculture for sustainable cities: Using wastes and idle land and water bodies as resources. Environment and Urbanization 4(2):141-152. doi: $10.1177 / 095624789200400214$.

Smith, C.M. and Kurtz, H.E. 2003. Community gardens and politics of scale in New York City. Geographical Review 93 (2):193-212.

Sustain 2014. Planning Sustainable Cities for Community Growing: A Guide to Using Planning Policy to Meet Strategic Objectives through Community Food Growing. Sustain: The Alliance for Better Food and Farming, London.

Tompkins, M. 2014. Making space for food: Everyday community food gardening and its contribution to urban agriculture. PhD thesis, University of Brighton.

Tornaghi, C. 2014. Critical geography of urban agriculture. Progress in Human Geography 38(4):551-567. doi: $10.1177 / 0309132513512542$.

Unruh, A.M., Smith, N., and Scammell, C. 2000. The occupation of gardening in life-threatening illness: A qualitative pilot project. Canadian Journal of Occupational Therapy 67(1): $70-77$.

Westphal, L.M. 2003. Social aspects of urban forestry: Urban greening and social benefits: A study of empowerment outcomes.

Zezza, A. and Tasciotti, L. 2010. Urban agriculture, poverty, and food security: Empirical evidence from a sample of developing countries. Food Policy 35(4):265-273. 